\title{
Public Policy Analysis on Implementation of Special Education Teacher's Recruitment in Inclusive Schools, Surabaya
}

\author{
Prastiyono $^{1} \quad$ Rudy.V.Handoko ${ }^{2} \quad$ A. Sjafii ${ }^{2} \quad$ Lukman Yudho Prakoso $^{3}$ Wuri Retno Martani ${ }^{4 *}$ \\ 1.Administration Doctoral Student, 17 August 1945 University, Surabaya \\ 2.Lecturer in Administration Doctoral Study Program, 17 August 1945 University, Surabaya \\ 3.Lecturer in Strategy of Sea Defense, Indonesia Defense University, Bogor \\ 4.Peace and Conflict Resolution Magister Student, Indonesia Defense University, Bogor
}

\begin{abstract}
The government of Surabaya received an International award as the organizer city of inclusive schools in 2014 . Researchers view that there are still problems with the implementation of Special Education Teacher's Recruitment, therefore the current research aims to find solutions in order to optimize the implementation of inclusive schools in Surabaya. Researchers used George Edward III's public policy implementation theory and descriptive qualitative with a phenomenological approach as the method. The result of analysis and discussion on the communication factor is still found that communication was not going well between the policy makers, policy implementers and policy recipients. In the resources factor is the resouces are still limited, thus made the fulfillment in recruiting special education teacher is not as expected, such as the availability of special education teacher is still limited as well as the supporting facilities. It was found in the disposition factor that the commitment of Surabaya's government in organizing an inclusive school is high but they still could not meet the ideal of The Special Education Teacher whereas the fulfillment still relied on regular teachers who were given training, which teachers should have Special Education background. In the factor of bureaucratic structure, it was found that every school designated as an inclusive school used standard procedures that are different in each school, this is because Surabaya does not have a policy related to the implementation of inclusive school. The finding in supporting factor is the existence of regulations which support the implementation of inclusive schools, meanwhile the inhibiting factor is the availability of a budget for procurement of ideal special education teachers which is still minimal. The finding of Special Education Teacher Recruitment model are Recruitment of Special Education Teacher through assessment. As the conclusion, the implementation Special Education Teacher Recruitment in inclusive schools Surabaya has not been optimal since the government does not have regulations. Therefore, the recommendation of this research is that the implementation of inclusive schools must be evaluated immediately before the ideal Special Education Teachers can be fulfilled as well as regulation on implementing of inclusive schools in Surabaya should be made immediately.
\end{abstract}

Keywords: Inclusive schools, special education teacher, recruitment.

DOI: $10.7176 /$ PPAR/10-1-05

Publication date: January $31^{\text {st }} 2020$

\section{Introduction}

The government of Surabaya prioritize the development of inclusive schools for children with special needs for primary and junior high schools in a number of areas in the City of Heroes, East Java. The development of children with specaial needs is a part of the priorities of the government since there are many of them come from poor families and some are abandoned by ther parents (Prastiwi, 2019).

The government of Surabaya has developed around 78 inclusive schools, with each child who is unique and has different talents and skills to be developed. To support this, the government has prepared a variety of skills training, such as sports, arts, and music in public spaces like city halls and city parks.

The development of inclusive shools in Surabaya has became one of the material delivered by Surabaya's Mayor, Tri Rismaharini when she was lined up as the first representative of Indonesia as one the speakers in The 10th St. Petersburg International Educational Forum in Rusia on March 25, 2019 to March 29, 2019. The forum which was attended by more than 20 thousand people from various countries, aimed at discussing educational issues from around the world.

In implementing inclusive schools, adequate input instruments are required to support the success of inclusive program. One of them is the role of the Special Education Teachers (GPK). GPK is a teacher who assisted children with special needs in teaching and learning process in regular classes that are qualified for Special Education (PLB) or who have received training on the implementation of inclusive schools. Special Education Teachers are teachers who have special educational background (PLB) whose task is bridging the difficulties of children with special needs (ABK) and class/subject teachers in learning process and perform special tasks that are not performed by teachers in general (Minister of National Education Regulation No.70, 2009).

Special Educational Teacher as a center of education that has important tasks in assisting children with 
special needs, own assignments and roles in the implementation of inclusive schools which are elaborated in Ministrial Regulation on National Education No. 70 of 2009 which includes: (1) along with classroom teachers and lesson teachers arrange educational assessment instruments, (2) building a coordinating system between teachers, schools, and parents of the students, (3) carrying out assistance of children with disabilities in learning activities along with the classroom teachers/lesson teachers, (4) providing special service assistance for children with disabilities who experience obstacles in participating in learning activities in general classes, in the form of remidial or enrichment, (5) providing guidance on a sustained basis and make special notes for children with disabilities during the learning activities, which can be understood if there is a change of teacher, (6) providing help (share experience) with classroom teachers and/or lesson teachers therefore they can provide educational services to children with disabilities.

The low role in the performance of inclusive teachers, in this case Special Education Teachers, classroom teachers and subject teachers, is confirmed by the findings of research conducted by the Helen Keller International Team (2011) in several provinces, one of which is the capital city of Jakarta. It is explained that teachers gaining knowledge and skills only through a socialization program. This means teacher has not gained sufficient competence in teaching children with special needs (ABK) in inclusive schools. Inclusive schooles are schools that provide opportunities for children with special needs to learn together with children in general in the same class (Kurniawati, 2017).

Based on the background above, researchers are interested in conducting research about the recruitment of Special Education Teachers (GPK) in Surabaya. Researchers received preliminary information on some complaints from parents whose children have special needs related to the special education teachers in inclusive schools in Surabaya. This research aims to analyze how the implementation of special education teachers recruitment process, supporting and obstacle factors, and finds the best model regarding to the recruitment of special education teachers so that the implementation of inclusive schools in Surabaya can be optimized and better.

\section{Literature Review}

Theory used to analyze the issues of Special Education Teachers Recruitmen process in Surabaya in this research is George C. Edward III which stated that the factors influencing the success of policy implementation are divided into four factors or variables of the policy, there are bureaucratic structure, resources, communication and disposition (Edward, 1980).

\section{Research Method}

The method used in this research is descriptive qualitative with phenomenological approach. According to Johann Heinrich Lambert, phenomenology is intended as a basic theory of appearance to study empirically about the knowledge of sensory appearance (Creswell, 1998).

\section{Discussions}

\subsection{Implementation of Special Education Teacher's Recruitment in Surabaya}

From the informant's statement in the research on implementation of Special Education Teacher Recruitment's policy in Surabaya, the researcher provide an analysis and discussion that the existence of Special Education Teacher in inclusive schools, Surabaya is in alarming condition. This condition cannot be tolerated considering that it can endanger children with special needs, thus the implementation of inclusive schools in Surabaya must be stopped immediately and evaluated.

The implementation of communication factor, what is done by Surabaya's Education Authorities is no longer in line with Ministry of Education Regulation No. 70 of 2009. Instead using teachers who are having special educational backgrounds, teachers used in inclusive schools are taken from regular teachers who teach academic subjects in daily. This condition is added by the fact that some parents insisted their children to enter an inclusive school, even though their child's criteria should be in Special Schools (SLB).

In resources factor, the government clearly has constraints on budgets for Special Education Teacher's Recruitment, thus the provisions are not implemented in accordance with the Ministry Regulations. Budgetary contraints also have an impact on the availability of inclusive schools facilities. Facilities that available to support children with special needs learning activities are only in modest.

Implementation on disposition factor is that Surabaya's Education Authorities is committed to carry out inclusive school, yet this attitude is not accompanied by the availability of Special Education Teacher Recruitment which is in accordance with the criteria. This factor does not only affect the results of children with special needs education, but also endangers the existence of the children in inclusive schools.

In bureaucratic structure factor's implementation, it is very significant. It was found that inclusive schools do not have a policy base from the government. This is very different with other province and districts/cities that already have a platform for holding inclusive schools in their area. It also affects the availability of Standard 
Operating Procedures (SOP) in inclusive schools in Surabaya.

\subsection{Supporting and Inhibiting Factors}

The results of analysis and discussion about implementation of Special Education Teachers Recruitment's policy in Surabaya found several supporting and inhibiting factors, as follows:

1.The supporting factor is the commitment of Surabaya's government to keep fulfill all the needs that are required in order to make the government provide the best service to children with special needs. The steps taken include providing 78 inclusive schools which are elementary and junior high school level. The government of Surabaya is also stratified and continues in recruiting Special Education Teacher.

2.As inhibiting factor which is budget limitation for Special Education Teacher, recently, the government is taking the teachers from regular teachers who are given inclusive training. Budget limtation also impacts the availability of facilities that should be given to support the implementation of inclusive program for children with special needs.

\subsection{Findings on Special Education Teacher's Recruitment Model}

Based on the results of discussion in the implementation of Special Education Teacher recruitment policy in Surabaya which discusses about the communication, resources, disposition and bureaucracy structure factor, as well as considering the supporting and inhibiting factors in implementing policy, the researcher formulated the findings of Special Education Teachers Recruitment model as follows:

Current condition is related to the recruitment process of Special Education Teachers in Surabaya. The recruitment process is carried out by taking the teachers from regular academic schools whose their responsibility are giving lessons to the students in daily life. The training material that was carried out was not quite related to the time of implementation and the material provided.

The condition which is expected related to the recruitment of Special Education Teacher is that the recruitment process should have in accordance with Ministry of National Education Regulation No.70 of 2009. Teachers who are recruited must have Special Education background. In addition, every teacher should has specialization based on the children's type, such as Blind, Deaf, Mentally disabled, and Physically disabled.

Faced with the reality that the least children with special needs graduates, the findings in recruitment model of Special Education Teacher in this research are that the model of recruitment can be carried out by utilizing outputs of tertiary education programs which is being given a training based on the needs of children with special needs, and all of the training must through the assessment before obtaining a statute as Special Education Teacher. The teacher's recruitment taken from regular academic teachers who have been actively teaching is not recommended, considering its availability which is limited in the recruitment process. In case the regular teachers are still recuited, then it will be a concerned that teachers will out of focus since they are carrying out multiple tasks and responsibilities.

\section{Conclusion}

The conclusion of this research is that the implementation of Special Education Teachers Recruitment policy in inclusive schools in Surabaya is not optimal. The supporting factors that the government committed in continuing to complement the needs of inclusive schools must be supported by the existence of a basic policy. The recruitment process which taking regular teachers cannot be justified since they have been functioning as academic teachers. The double task of regular teachers as academic teachers and Special Teachers can endanger the children with special needs.

Based on the conclusions above, the recommendations of this research are: the recruitment process of Special Education Teachers in Surabaya must be immediately evaluated. The government should carry out this Research Recommendation, especially the model of Special Education Teacher's Recruitment, besides having Special Education background, the recruitment process can also be done by taking the educational products from higher education students which are given training and assessment before they are assigned as Special Education Teachers.

\section{References}

Creswell, John W. (1998), “Qualitative Inquiry and Research Design, Choosing Among Five Traditions”, Sage Publication, California

Edward, George III. (1980), "Implemeting public policy"

Kurniawati, Lia (2017), "Pembelajaran Pendidikan Inklusi Pada Sekolah Dasar", Edutech Journal is a journal managed by Educational Technology Study Program Universitas Pendidikan IndonesiaDOI: https://doi.org/10.17509/e.v16i2.6152

Minister of National Education Regulation No.70/2009 on Inclusive Education for students with Potential Intelligence and / or Special Talent. 
Prastiwi, Elva Nurrul. (2019), "Pemkot Surabaya Kembangkan Sekolah Inklusi”, https://www.gesuri.id/kerakyatan/pemkot-surabaya-kembangkan-sekolah-inklusi-b1WelZiNC, accessed on November 24, 2019 